\title{
Exposed Biologies and the Banking of Reproductive Vitality in China
}

Wahlberg, Ayo

Published in:

Science, Technology and Society

DOI:

$10.1177 / 0971721818762895$

Publication date:

2018

Document version

Peer reviewed version

Citation for published version (APA):

Wahlberg, A. (2018). Exposed Biologies and the Banking of Reproductive Vitality in China. Science, Technology and Society, 23(2), 307-323. https://doi.org/10.1177/0971721818762895 
This paper has been accepted for publication in Science, Technology \& Society, and the final (edited, revised and typeset) version of this paper will be published in Science Technology \& Society: 23(2), April 2018 by Sage Publications Ltd, All rights reserved. () Sage Publications Ltd, 2018

\title{
Exposed Biologies and the Banking of Reproductive Vitality in
}

\section{China}

Ayo Wahlberg, Department of Anthropology, University of Copenhagen, Øster Farimagsgade 5, 1353 Copenhagen, Denmark, ayo.wahlberg@anthro.ku.dk

\begin{abstract}
The looming figures of smog-choked cities, cancer villages and contaminated food have become iconic of a modernizing China; the tragic, perhaps unavoidable, side effects of a voracious economy. In this article, I examine how the sperm bank - jingzi ku - in China has emerged quite literally as a sanctuary of vitality amidst concerns around food safety, air and water pollution, rising infertility and declining population quality. As a twist on Margaret Lock's concept of 'local biologies', I argue 'exposed biologies' have become a matter of concern in China in ways that have corroborated a place for hi-tech sperm banks within China's restrictive reproductive complex. Exposed biologies are a side effect of modernisation processes, as industrially manufactured chemicals are increasingly held culpable for a range of pathologies, from cancers to metabolic diseases, disorders of sex development and infertility. Amidst concerns that pollution and modern lifestyles are deteriorating sperm quality in China, the sperm bank stands out as a repository of screened, purified and qualitycontrolled vitality and as such sperm banking can be seen as a form of reproductive insurance, not only for individuals but also for the nation.
\end{abstract}

\section{Key words}


This paper has been accepted for publication in Science, Technology \& Society, and the final (edited, revised and typeset) version of this paper will be published in Science Technology \& Society: 23(2), April 2018 by Sage Publications Ltd, All rights reserved. () Sage Publications Ltd, 2018

Sperm banking, sperm quality, exposure, pollution, China

\section{Introduction}

In the summer of 2008, a news feature aired on the Shanghai News Channel with a montage of images showing crowded cities, high-tech laboratories and office workers. As these urban images flashed by a voice-over explained how:

[f]ive years ago, a sperm bank was founded in Shanghai, with the goal of providing sperm to infertile couples for artificial insemination. Five years on, according to many news reports, the sperm bank has found itself in great difficulties and the sperm crisis (jingzi weiji) era has begun. What has caused this sperm crisis?... With increasing industrialisation, sperm quality worldwide is declining. Life pressure, smoking, drinking, pollution, lack of exercise, dressing the wrong way, and radiation from mobile phones and computers have all become hidden killers affecting sperm density and motility... Since the day the sperm bank was founded, [Director] Li Zheng has faced two problems. One is the poor quality of sperm, the other is the shortage of sperm donors, which has directly caused this sperm crisis. (Shanghai News Channel 2008)

In the eight years (2007-2014) that I carried out fieldwork in Changsha, Beijing, Changsha and Guangzhou for a project on the routinisation of sperm banking in China, food safety scandals and an unfolding 'environmental crisis' (buanjing weiji) were palpable. From melamine-tainted milk powder to contaminated drinking water, discarded gutter oil collected for resale, fake eggs and toxic dumplings, crook imaginations, it seemed, knew no bounds in the throes of a voracious economy 
This paper has been accepted for publication in Science, Technology \& Society, and the final (edited, revised and typeset) version of this paper will be published in Science Technology \& Society: 23(2), April 2018 by Sage Publications Ltd, All rights reserved. () Sage Publications Ltd, 2018

(Wahlberg 2013). And as if such food safety compromising scandals weren't hazard enough, residents in many of China's cities and so-called 'cancer villages' (aizheng cun) were conspicuously choking in smog while polluted rivers flowed by. In 2007, my colleagues and informants would rarely talk of pollution, speaking resignedly instead of the 'heavy fog' outside, even on days where the indoor corridors outside our offices were hazy. If pollution was the price to pay for rising living standards, there was no sense in lamenting. Nevertheless, the shrugs I had met early on in fieldwork had turned into a sense of anxious helplessness by the end of it. During one of many weekend meals at a Changsha restaurant in 2013, a couple of doctors recounted a morbid joke that was making the rounds at their hospital: 'Eating food will give us stomach cancer, drinking water will give us liver cancer and breathing air will give us lung cancer'. Their deadpan juxtaposition of vital activity with deadly outcome hung over the rest of the meal and beyond: urban living was toxic living in China.

Based on fieldwork in the village of Baocun in Yunnan province, Anna Lora-Wainwright and colleagues have shown how over the last decades a new form of environmental subject has emerged in rural China as villagers 'have come to resent environmental degradation and to recall a cleaner past' (2012: 109). Emergent environmental activism notwithstanding, Liu Lee has argued that rural farmers 'tend to feel hopeless after years of failed attempts to fight the polluters, and most give up... Desperate villagers sometimes gather to block traffic to the factories or tamper with their water supply systems in order to gain attention' (Liu 2010: 16), and in a survey study from Beijing, Wong concluded that university students 'held pessimistic attitudes towards future environmental conditions, and the majority anticipated a decline in environmental quality' (2003: 536). And so, while a certain form of environmental awareness has emerged in China in recent decades, scholars 
This paper has been accepted for publication in Science, Technology \& Society, and the final (edited, revised and typeset) version of this paper will be published in Science Technology \& Society: 23(2), April 2018 by Sage Publications Ltd, All rights reserved. () Sage Publications Ltd, 2018

suggest that this awareness has been tempered by a sense of resignation and pessimism (see LoraWainwright 2017).

In this article, I show how the sperm bank - jingzi ku - in China has emerged quite literally as a sanctuary of vitality amidst concerns around food safety, rising infertility, declining population quality, environmental pollution and indeed a national 'sperm crisis' (jingæi weiji). As a twist on Margaret Lock's concept of 'local biologies', I suggest that 'exposed biologies' have become a matter of concern in China (and globally) in ways that have corroborated a place for sperm banks within China's restrictive reproductive complex over the last three decades (see Wahlberg 2016). Sperm banking is primarily a technology for treating male infertility in China, and as we will see, the problem of infertility has in recent years become inextricably wound up in rising concerns about the health effects of pollution on Chinese bodies. Lock originally proposed the notion of local biologies in her comparative study of the different ways in which ageing was encountered in Japan and North America, arguing that further to the cultural constructions that surround ageing processes, it seems most likely that the traditional Japanese diet—low in fat, high in protein and natural estrogensplays an important role in both low symptom reporting at the end of menstruation and in longevity' (Lock \& Kaufert 2001: 500). The concept of local biologies, then, allows us to account for how 'biological difference - sometimes obvious, at other times very subtle - moulds and contains the subjective experience of individuals and the creation of cultural interpretations' (Lock 1993: 39).

In contrast, exposed biologies are a side effect of modernisation processes, as industriallymanufactured chemicals and modern forms of living are increasingly held culpable for a range of pathologies, from cancers to metabolic diseases, respiratory troubles, cardiovascular conditions, disorders of sex development and infertility. Whereas 'traditional' diets and lifestyles such as those 
This paper has been accepted for publication in Science, Technology \& Society, and the final (edited, revised and typeset) version of this paper will be published in Science Technology \& Society: 23(2), April 2018 by Sage Publications Ltd, All rights reserved. () Sage Publications Ltd, 2018

found in Japan or Mediterranean countries are often lauded for their health benefits, 'modern' diets and lifestyles - sedentary; high in fat, sugar and salt - are blamed for their negative health impacts. This is 'food as exposure' in Hannah Landecker's (2011) phrase, yet, we should be careful not to confuse exposed biologies with particular diets or lifestyles. As my doctor colleagues' dinner joke highlights, it is impossible to avoid exposure when it is an ingrained part of vital activity - breathing, drinking, eating, working, etc. Exposed biologies are not so much culturally formed as they are tied to the moment when endocrine-disrupting, carcinogenic or dysgenic chemicals were 'released into the environment in large quantities [especially] since World War II' (Colborn, von Saal \& Soto 1993: 378), exposing all irrespective of diet or lifestyle to harmful chemicals in greater or lesser intensities. Indeed, scientists have argued that 'It is now virtually impossible to identify an unexposed population around the globe' (UNEP \& WHO 2013: xv). Unlike the after effects of disasterintensified exposure that Adriana Petryna (2002) has ethnographically documented in postChernobyl Ukraine and Kim Fortun (2009) in post-Bhopal India, this is everyday exposure that affects most people in the world, especially those who are living with persistent pollution on a daily basis like those rural Chinese villagers Anna Lora-Wainwright (2017) has studied. Consequently, we can say that what Michelle Murphy has called chemical infrastructures - 'the spatial and temporal distributions of industrial chemicals and their diverse effects on life' (Murphy 2013: 106) - and the chemical regimes of living (Murphy 2008) that form within them, are now ubiquitous in all parts of the world.

In China, public health experts have recently red-flagged a perfect storm for exposed biologies: 'rapid urbanisation and changes in dietary and lifestyle choices' (Hu et al. 2011: 552) not least linked to the spread of industrially-processed foods (at times of dubious quality and safety); 
This paper has been accepted for publication in Science, Technology \& Society, and the final (edited, revised and typeset) version of this paper will be published in Science Technology \& Society: 23(2), April 2018 by Sage Publications Ltd, All rights reserved. () Sage Publications Ltd, 2018

industrially-contaminated water that has been blamed by some researchers in the post-reform emergence of "cancer villages" (aizheng cun) (Liu 2010); and the air pollution that regularly blankets many of China's cities causing 'between 350,000 and 500,000 people' to die prematurely each year from cancers and respiratory diseases (Chen et al. 2013). This is what Janelle Lamoreaux has called 'a toxic China' where developmental and toxicological researchers have come to understand the environment as 'a lineage of personal and chemical exposures' (2016: 191). Over the course of my research I came to think of this perfect storm as China's Anthropocene - a historical moment when anthropogenic effect was being detected, not so much in atmospheric carbon dioxide levels, glacial ice cores or sea levels, but rather in levels of carcinogens, mutagens, obesogens, teratogens and endocrine disruptors found in the human body (see Wahlberg 2013). As we will see in the following, in China (as elsewhere), infertility has been directly linked to the exposed biologies that have followed in the wake of post-reform industrial growth.

The article is based on eight years of episodic fieldwork (Whyte 2013) primarily in Changsha (at China's oldest and largest sperm bank), capital of Hunan province, but also in Beijing, Shanghai and Guangzhou consisting of ten trips lasting between 3 months and a couple of weeks. The fieldwork has been guided by the question of how routinized sperm banking has become possible in China. As such, my research has involved participant observation at sperm banks, interviews with doctors, sperm bank managers and sperm donors, attendance at scientific conferences and the collecting of documents in equal measure. Consequently, the analysis that follows is based on field notes, interview transcripts, medical journal articles, media reports, regulations, guidelines, conference reports, 'grey literature' in the form of brochures and leaflets, donor screening criteria and standard operating procedures. 
This paper has been accepted for publication in Science, Technology \& Society, and the final (edited, revised and typeset) version of this paper will be published in Science Technology \& Society: 23(2), April 2018 by Sage Publications Ltd, All rights reserved. () Sage Publications Ltd, 2018

I begin by surveying the science of exposure when it comes to developmental sex disorders and infertility, focusing in particular on testicular dysgenesis and endocrine disruption hypotheses. I show how exposure to industrial chemicals, together with the modern lifestyles that are seen as intensifying such exposure, have emerged as culprits for apparently rising rates of infertility. While dysgenesis and endocrine disruption hypotheses remain contested ${ }^{i}$, I subsequently demonstrate how they nevertheless have taken on a social life of their own in China, circulating through alarmist news reports and expert meetings which in turn have contributed to a socially-diagnosed national 'sperm crisis'. Finally, I argue that China's quality-controlled sperm banks have emerged as sanctuaries of vitality, state-sanctioned sites where 'good quality' sperm can be collected and stored as reproductive insurance for individuals, for use by infertile couples as well as for the sake of the nation.

\section{Declining sperm quality and reproductive insurance}

While carrying out fieldwork at the Hunan sperm bank in Changsha one afternoon in May 2013, I came across a flyer in the waiting room for sperm donors, which was titled "Reproductive Insurance". I asked Li, one of the doctors who screened potential donors at the sperm bank, why this flyer was made available to sperm donors as I presumed that healthy donors were not the target group for a technology that I had thought was most relevant for men with serious diseases such as cancer. And indeed most of the flyer was dedicated to explaining how reproductive insurance freezing one's sperm for later reproductive use - was 'good news for male patients with cancer who have not yet had children'. Li responded by suggesting that some of their donors would perhaps go on to suffer from cancer so they might consider preserving some of their sperm not only for 
This paper has been accepted for publication in Science, Technology \& Society, and the final (edited, revised and typeset) version of this paper will be published in Science Technology \& Society: 23(2), April 2018 by Sage Publications Ltd, All rights reserved. () Sage Publications Ltd, 2018

recipient couples but also as an insurance for themselves. Moreover, he pointed out, some of their donors might end up working in dangerous environments which could affect their fertility. On the back page of the flyer, the sperm bank listed five groups as potential customers of reproductive insurance for men:

\section{The main groups that reproductive insurance... are aimed at:}

1. Patients who need to do a sterilizing operation or males with serious diseases. For example, sperm can be cryopreserved before an orchiectomy, an operation on the epididymis, and chemotherapy or radiation therapy for patients with cancer which will affect sexual function 2. Men who want to prevent infertility caused by accidents. For example, soldiers going to war, astronauts, people who work in scientific research and exploration 3. People working in long-term jobs which affect reproductive ability, who are exposed to a large amount of volume radiation or poisonous substances. Before beginning work in these environments, they can cryopreserve their sperm, so if in the future there is a severe low sperm count or no sperm, they can use the frozen sperm for artificial insemination 4. Men who are married and have children at a late age for work or career reasons 5. Patients with a low sperm count (oligospermia), low sperm motility, abnormal sperm, or obstructive azoospermia. The sperm from their testicles and epididymis can be cryopreserved for future, intracytoplasmic sperm injection treatment.

(Reproductive Insurance flyer, Hunan Sperm Bank)

As such, reproductive insurance was for those men who were not planning to establish a family at the moment but who would like to minimise the risk of future infertility by freezing their 'good' - or at least 'better' - reproductive vitality today. In recent years, social freezing of eggs has emerged as a controversial issue in many countries as cryobanks encourage young women to freeze their oocytes now to counter an inevitable fertility decline while they finish their education and establish their careers (Mertes \& Pennings 2011). Since extraction of eggs from women is only allowed in connection with IVF in China, only married women are eligible to undergo cycles of ovarian 
This paper has been accepted for publication in Science, Technology \& Society, and the final (edited, revised and typeset) version of this paper will be published in Science Technology \& Society: 23(2), April 2018 by Sage Publications Ltd, All rights reserved. () Sage Publications Ltd, 2018

stimulation. As a result, social freezing of eggs is currently not a legal option for young single women, which has led some well-off individuals to travel abroad to access this service (Zhang 2016). Yet as we can see here, social freezing of sperm is an option for those men who are advised by the sperm bank in its brochure to 'anticipate infertility' (Martin 2010) in the face of risks that dangerous or toxic occupations might impose on them or because they are deferring reproduction. This is possible because the regulation on Basic Requirements and Technical Specification of Human Sperm Banks issued by the Ministry of Health states that 'The aim of sperm banks is to provide treatment for infertility, prevention of genetic disease and reproductive insurance' (MoH 2003). In China, concerns about declining sperm quality have contributed to a media-diagnosed 'sperm crisis' in recent years even if andro-epidemiological claims of declining national sperm quality can be hard to verify. The science around aggregated sperm quality is contested both when it comes to whether or not there has been a decline in China's - or any other country's - overall sperm quality and whether or not anthropogenic processes set in motion by compressed industrialisation and urbanisation in recent years are to blame. Nonetheless, ever since Carlsen and colleagues concluded in a 1992 global review study that 'there has been a genuine decline in semen quality over the past 50 years' (Carlsen et al. 1992: 609) it has become something of truism. In China, one of the first andro-epidemiological studies was carried out by researchers at the Science and Technology Institute of the National Population and Family Planning Commission in Beijing who analysed sperm samples from a total 11,726 men from 39 cities and counties from 1981 to 1996 finding that sperm quality had declined at an annual rate of $1 \%$ as sperm motility and normal sperm morphology rates decreased by $10.4 \%$ and $8.4 \%$ from 1981 to 1996 , amounting to a total decline of $40 \%$ or more (Zhang et al. 1999). Since then, a string of cohort studies have emerged, especially in the last five 
This paper has been accepted for publication in Science, Technology \& Society, and the final (edited, revised and typeset) version of this paper will be published in Science Technology \& Society: 23(2), April 2018 by Sage Publications Ltd, All rights reserved. () Sage Publications Ltd, 2018

years or so which have similarly concluded: 'In these 5 years [2007-2012], sperm concentration and the percentage of sperm normal morphology were decreased' (Jiang et al. 2014: 842); 'we also found a decrease in sperm concentration during the 4 years of observation' (Rao et al. 2015: 111); and finally, most recently, staff at the sperm bank in Changsha examined their sperm quality records from 30,636 young adult men who applied to be sperm donors between 2001-2015 and found that 'the semen quality among young Chinese men has declined over a period of 15 years, especially in terms of sperm concentration, total sperm count, sperm progressive motility, and normal morphology' (Huang et al. 2017: 83).

Even though pretty much every andrologist I have read research from or met in China have had reservations about such conclusions ${ }^{\text {iii }}$ they have nonetheless expressed their reservations in ambiguous terms which seemed to convey that they shared some kind of suspicion that sperm quality is indeed falling in China. For example, one head of a sperm bank noted that 'without accurate statistics, we cannot make the arbitrary judgment that mankind is facing a health crisis' while at the same time suggesting that thinking back 'there were more people who could generate 60 million sperm per millilitre twenty years ago'. Another doctor told a reporter from Qingdao News that whereas a test tube would have been full of ejaculate in the past, today it is only $1 / 3$ full on average. 'Human sperm density has decreased by half in 60 years' he explained, 'and if it continues to develop like this, we cannot imagine the consequences in a further 60 years' (cited in Qingdao News 2005). And another sperm bank director suggested to me that 'sperm quality has declined, but not to that terrible an extent.' And so, we can say that while not necessarily an established scientific fact in China today, decreasing national sperm quality has in some ways become a scientific fait accompli 
This paper has been accepted for publication in Science, Technology \& Society, and the final (edited, revised and typeset) version of this paper will be published in Science Technology \& Society: 23(2), April 2018 by Sage Publications Ltd, All rights reserved. () Sage Publications Ltd, 2018

which has been cemented by the symbolic traction that falling national sperm quality has gained as a form of social commentary, as we will see.

\section{Jingzi weiji-Sperm crisis}

The Shanghai News Channel whose feature I cited in the opening of this article was not alone in propagating a storyline of crisis around male fertility. Indeed, 2008 turned out to be the year that a 'sperm crisis' and related 'national emergency' were declared in Chinese media. A health news report from December 2008 in Henan proclaimed a 'national emergency in sperm banks in China' when only 37 out of 328 potential donors qualified for donation (Dàhé Jiànkāng Bào 2008). In that same year Professor Cao Xingwu, chief physician at the Ministry of Health China-Japan Friendship Hospital who had carried out research on sperm quality for some 15 years told a reporter from the

Life Times that 'If this trend continues, men will die without sons within 50 years!', just as Liu Dalin a Professor of Sociology from Shanghai University warned: 'Do not let Man become an endangered animal' (cited in Sina News 2008). In Guangzhou, journalists put numbers to the emergency under the headline 'Guangzhou sees alarming increase in the prevalence of male infertility' when they reported a few years later in June 2010 that: 'Now the sperm quality of a man in Guangzhou has declined by $50 \%$ compared with 50 years ago... the quality and quantity of sperm have declined, which is a problem we need to attach great importance to' (Xtata 2010).

To be sure, Chinese male fertility scientists and media are not alone in invoking the language of crisis and emergency, instead they tap into growing global concern with anthropogenic effect. Much of hitherto social science engagements with Anthropocene have 
This paper has been accepted for publication in Science, Technology \& Society, and the final (edited, revised and typeset) version of this paper will be published in Science Technology \& Society: 23(2), April 2018 by Sage Publications Ltd, All rights reserved. () Sage Publications Ltd, 2018

concerned the ways in which humans and non-humans (or 'more than humans') are imbricated in environmental and ecological networks and entanglements (Latour 2014; Tsing et al. 2017). This makes sense since the notion itself has emerged out of debates between geologists, climate scientists and marine biologists about whether or not the 'scale of human modification of the earth' in the past century can be compared to the meteorite strikes, tectonic collisions or volcanic eruptions that are seen to have punctuated previous geological eras (Wahlberg 2013). Consequently, scientists have set out to determine whether a 'human imprint' can be perceived in the atmosphere, sedimentation, glacial ice cores, biota, oceans, and more. Indeed, an Anthropocene Working Group was formed in 2009 'to critically compare the current degree and rate of environmental change, caused by anthropogenic processes, with the environmental perturbations of the geological past' with a call to include botanists, zoologists, atmospheric scientists, ocean scientists, as well as geologists in this task (Zalasiewicz et al. 2010: 2230).

However important social scientific investigations of new forms of living on a 'damaged', 'disturbed' or 'modified' earth have been, in theorizing Anthropocene we must also shift focus from the earth to the human body. For, around the same time that the Anthropocene Working Group convened, another workshop was organised in Copenhagen to discuss the possible effects of chemical toxicants found in consumer products on human populations. At stake, according to the workshop's organisers, was nothing short of a crisis:

\footnotetext{
We stand before a reproductive crisis which we should take just as seriously as global warming ... Our species is in danger. Climate scientists have long insisted that we have evidence of climate change, and
} 
This paper has been accepted for publication in Science, Technology \& Society, and the final (edited, revised and typeset) version of this paper will be published in Science Technology \& Society: 23(2), April 2018 by Sage Publications Ltd, All rights reserved. () Sage Publications Ltd, 2018

\author{
now everybody knows we need to stop $\mathrm{CO} 2$ emissions. We are saying the same thing about the \\ reproductive crisis: we need to do something before it is too late (cited in Politiken 2007; see also \\ Wahlberg 2013) iv
}

Indeed, ever since Rachel Carson famously decried how in modern society 'toxic materials become lodged in all the fatty tissues of the body' (1962: 170), epidemiologists, endocrinologists, oncologists, embryologists, andrologists and other medical scientists have sought to measure, not atmospheric carbon dioxide levels or sea levels, but rather levels of carcinogens, endocrine-disruptors and other toxicants found in biological samples taken from large groups of volunteer human subjects (blood, semen, tissue, etc.) (Wahlberg 2013). Such research seeks to identify a toxic imprint within our cellular/molecular biologies and to determine whether this imprint is causative of pathology. In this sense, exposed biologies have become yet another 'natural' element (alongside the atmosphere, sediments, oceans, flora, fauna, etc.) within which a 'human imprint' can be found. And, as we will see in the following, amidst media-led diagnoses of a 'sperm crisis' male reproductive bodies have emerged as yet another site of contestation over anthropogenic effect. ${ }^{\mathrm{v}}$

\title{
Dysgenesis
}

The search for a 'human imprint' within human bodies has been facilitated by a series of scientific hypotheses that have been formulated in the decades that followed the release of industrial chemicals into the environment in large quantities somewhere around the middle of the $20^{\text {th }}$ century 
This paper has been accepted for publication in Science, Technology \& Society, and the final (edited, revised and typeset) version of this paper will be published in Science Technology \& Society: 23(2), April 2018 by Sage Publications Ltd, All rights reserved. () Sage Publications Ltd, 2018

(Colborn, vom Saal \& Soto 1993). These include the chemical carcinogenesis hypothesis, the obesogen hypothesis and the endocrine disruption hypothesis. When it comes to human reproduction two hypothesised syndromes stand out as postulated in the testicular dysgenesis hypothesis and the ovarian dysgenesis hypothesis, both of which suggest a link between exposure to endocrine disruptors and increasing rates of male and female infertility. For the purposes of this article I will focus on dysgenesis as a particular feature of male exposed biologies all the while acknowledging the importance of attending to female exposed biologies in equal measure (see Murphy 2008).

The media-diagnosed sperm crisis or jingæi weiji in China can in some ways be traced to Danish andrologist Niels Skakkebæk's proposed 'new concept that poor semen quality, testis cancer, undescended testis and hypospadias are symptoms of one underlying entity, the testicular dysgenesis syndrome (TDS), which may be increasingly common due to adverse environmental influences' (Skakkebæk et al. 2001: 972). Skakkebæk's research group was the one that had organised the abovementioned international workshop bringing together scholars from around the world with a common interest in the effects of endocrine disruption on reproduction. In a recent review article titled "Human infertility: are endocrine disruptors to blame?" Marques-Pinto and Carvalho suggest that TDS symptoms 'probably arise from intrauterine disruption of proper testicular development and function under ED [endocrine disruptor] exposure' (2013: R15). It is this disruption of proper testicular development that is subsequently thought to be causative of dysgenesis and subsequent falling sperm quality as well as rising incidences of testicular cancers and sex disorders.

As Janelle Lamoreaux (2016) has shown, toxicological research into the effects of pollution on fertility and population quality in China has taken off in the last decade or so. Indeed, a report in 
This paper has been accepted for publication in Science, Technology \& Society, and the final (edited, revised and typeset) version of this paper will be published in Science Technology \& Society: 23(2), April 2018 by Sage Publications Ltd, All rights reserved. () Sage Publications Ltd, 2018

the South China Morning Post from December 2013 suggested that the number of fertility studies funded by the National Natural Science Foundation of China had tripled in the preceding five years. In the news report, Liu Liangpo from the Institute of Urban Environment at the Chinese Academy of Sciences makes a disturbing argument: 'Polluted water, unsafe food, bad air ... so many things are threatening the reproductive capacity of Chinese people. If the situation gets worse, China's birthcontrol policy would become redundant' (cited in South China Morning Post 2013). Reproductive toxicologists throughout China have benefited from increased funding, and just as we have seen a flurry of epidemiological studies on apparently declining sperm quality in China, we are also seeing an increasing number of studies focused on the negative effects of pollution on male infertility. For example, Wu and colleagues concluded in a recent toxicological study that 'that ambient PM [particulate matter from air pollution] exposure during sperm development adversely affects semen quality, in particular sperm concentration and count' (Wu et al. 2017: 219) just as Guo and colleagues have concluded that 'occupational CS2 [carbon disulphide] exposure can exert deleterious effects on male sexual hormones and sperm quality' (Guo et al. 2016: 294).

Now, just as the andro-epidemiological jury is still out as to whether there in fact has been a global or Chinese decline in sperm quality, so too is the toxicological jury on the dysgenesis hypothesis (underscored by the use of the qualifiers 'may be increasingly common', 'probably arise from' and 'can exert'). Yet, once again the symbolic traction that dysgenesis has gained in China leads me to argue that it has become a media-aided scientific fait accompli. Take this selection of national and international newspaper by-lines that I collected while carrying out fieldwork: 
This paper has been accepted for publication in Science, Technology \& Society, and the final (edited, revised and typeset) version of this paper will be published in Science Technology \& Society: 23(2), April 2018 by Sage Publications Ltd, All rights reserved. () Sage Publications Ltd, 2018

- increase in male infertility is closely related to increasing pressure in day-to-day life and environmental deterioration' (China Daily 2011)

- 'Various kinds of pollutions make sperm quality decline' (Sohu 2011)

- 'Male infertility rate on the rise - Radiation from cell phones, computers and other electronic devices, air, water and food pollution, combined with the sedentary lifestyle followed in cities are to blame for a possible "quality decline” of sperm' (China Daily 2009)

- 'pollution, stress blamed for poor China sperm count' (Reuters 2007)

Through such media reporting, exposed biologies become palpable. In this diagnostic, biological difference is not the result of local lifestyles and diets, rather it is related to the intensity, timing and duration of exposure to industrial chemicals through the thoroughly mundane, vital daily activities of eating, drinking, breathing, working and moving around. Some sperm banks highlight the detrimental effects of environmental exposure on male fertility:

\footnotetext{
Do you wanna earn more money easily, without conflicts with your study? Do you wanna spend you spare time more meaningfully, doing something interesting and exciting? Yeah, now you can consider being a volunteer in the sperm bank...! Along with environmental deterioration, more and more males have become infertile, and some of them even need donor sperm insemination. (Recruitment flyer)
}

Likewise, many of the 50 potential and qualified sperm donors interviewed during fieldwork brought up the negative effects of pollution when asked whether they considered infertility to be a significant problem in China: 
This paper has been accepted for publication in Science, Technology \& Society, and the final (edited, revised and typeset) version of this paper will be published in Science Technology \& Society: 23(2), April 2018 by Sage Publications Ltd, All rights reserved. () Sage Publications Ltd, 2018

yes it is a very serious problem... erh it is because the environment is not very good, so sometimes they
want a baby but they can't have it and this is very disappointing. (22 year-old, university student, Shanghai)

I have an aunt, they live next to a factory so they went for IVF, you know pollution is causing infertility in China. As far as I know my aunt, they went to get IVF and the reason is his [husband's] house is next to a factory and the environment changed so they went to the Changsha hospital. (20 year-old, university student, Changsha)

There are about tens of millions of infertile people. I think the reasons are medical and more and more social pressure. Many people were fertile in the past, but they put off the time to bear children because of work and also because of social activities, environmental impact or other effects, all these slowly lead to infertility. (32 year-old, office worker, Guangzhou)

As in the case of local biologies, biological difference stemming from exposed biologies can be sometimes obvious, at others subtle, imbricating subjective experience and cultural interpretation. In its most intensified forms, exposed biologies can lead to cancer and death, yet there are many other forms where symptoms may not be immediately life-threatening yet still impacting on people's lived lives in substantial ways. For example, sufferers of the contested condition known as toxicantinduced loss of tolerance (TILT) report headaches, respiratory trouble, mood change, digestive problems, sleep disorders and more, just as multiple chemical sensitivity (MCS) is blamed for muscle pains, nausea and dizziness (see Shapiro 2015). In China, as anthropologist Mikkel Bunkenborg has shown, the emergence of the notion of sub-health (yajiankang) in the 1990s can be linked to 'apprehensions about the somatic effects of rapid modernisation' (Bunkenborg 2014: 128). Some 
This paper has been accepted for publication in Science, Technology \& Society, and the final (edited, revised and typeset) version of this paper will be published in Science Technology \& Society: 23(2), April 2018 by Sage Publications Ltd, All rights reserved. () Sage Publications Ltd, 2018

studies have suggested that up to $70 \%$ of Chinese suffer from sub-health which, much like TILT and MCS is characterised by a diffuse set of symptoms such as tiredness, hair loss, poor sleep quality, declining immune system and more and has been linked to environmental pollution (CCTV 2011).

When it comes to infertility, symptoms are not often noticeable until a couple is actively trying to achieve a pregnancy. And even if male infertility may not generate somatic discomfort, once diagnosed, the psychological consequences can be considerable for many men as they harbour feelings of shame, guilt and inadequacy (see Inhorn 2013; Tjørnhøj-Thomsen 2009). Yet, just as Lamoreaux argues that the toxicologists she studied in Nanjing discourage disease guilt and embarrassment by 'pointing to the many possible causes of the conditions [they study], ones that go beyond individualised behaviours, such as air and water pollution, food safety and availability, and changing lifestyle habits' (2016: 189), so too do circulating narratives of anthropogenic dysgenesis.

We can see then how infertility has come to be seen as a significant consequence of anthropogenic effect; a man-made problem, a side effect of China's economic policies which in turn are seen to have led to reproductive deferral, intensified exposures and modifications of lifestyle. Even if epidemiologists, andrologists and toxicologists usually temper their findings by suggesting that sperm quality 'is possibly' falling and that this decrease is 'probably' being caused by exposure to industrial chemicals, what I have argued is that these findings have nevertheless become scientific fait accompli in China because of their symbolic efficacy as a form of social commentary. So what then do China's sperm banks have to do with exposed biologies?

\section{Jingzi ku-minimizing exposure}


This paper has been accepted for publication in Science, Technology \& Society, and the final (edited, revised and typeset) version of this paper will be published in Science Technology \& Society: 23(2), April 2018 by Sage Publications Ltd, All rights reserved. (C) Sage Publications Ltd, 2018

'You see, we like to work here in the lab. It's quiet and cool, and we can enjoy chatting together.' Li, one of the doctors working part time at the sperm bank said this to me one afternoon as an assembly line of laboratory workers received sperm samples through a hatch which separated the outside clinical world from the Good Manufacturing Practice (GMP) facilities of the sperm bank, where samples were analysed and approved sperm prepared for cryopreservation. The organisation and lay out of the sperm bank separates an unsterilized and chaotic front stage from a quiet, airquality-controlled backstage. Staff at the sperm bank in Changsha worked on rotation, fulfilling the various required tasks of recruitment, reception and semen quality analysis, and all of them told me how they enjoyed getting laboratory duty. Even if laboratory tasks were to some extent mechanical and laborious, it was quiet and cool in the lab, in direct contrast to the cacophonic, chaotic and stressful clinic/sperm bank life that was going on outside. Moreover, the air quality of the laboratory was controlled to minimise risks of contaminating donor sperm making for a cool and comfortable working environment which was particularly attractive during Changsha's many hot summer months.

Although, as discussed earlier, reproductive insurance is one of the services offered by sperm banks in China, this service makes up for a very small proportion of their activities which are firmly focused on the recruitment of sperm donors for use in the treatment of infertility. Regulations in China prohibit reproductive clinics from providing fertility treatment to anyone but married couples who must provide copies of valid marriage and pregnancy certificates to prove their eligibility. Moreover, the development of surgical sperm retrieval and intracytoplasmic sperm injection techniques has allowed infertile men with very few sperm cells (if they can afford it) to nonetheless pursue their desires of having genetically-related offspring rather than opting for a sperm donor as they may have done before these techniques were available (see Inhorn 2013). Hence, today, it is 
This paper has been accepted for publication in Science, Technology \& Society, and the final (edited, revised and typeset) version of this paper will be published in Science Technology \& Society: 23(2), April 2018 by Sage Publications Ltd, All rights reserved. () Sage Publications Ltd, 2018

pretty much 'only' couples in which the man suffers from severely affected sperm quality that are the customers of China's sperm banks. Even so, with estimates of as many as two million azoospermic men (who are unable to produce their own sperm) in China (some of which are 'possibly' casualties of compressed modernisation), it will take a long time before sperm banks will be able to meet the (potential) demand for donor sperm. Indeed, shortages of donor sperm - or 'sperm drought' as one Director of a sperm bank in Europe has dubbed it - is a chronic feature of the Chinese infertility treatment scene.

Now, what I am suggesting in this article is that sperm banks are much more than a service for infertile couples where the male is diagnosed with azoospermia or for men interested in cryopreserving their fertility. In the face of a perceived national 'sperm crisis', sperm banks can also be thought of as a form of national reproductive insurance, recruiting as they do (explicitly so) among so-called 'high quality' (suそhi gao) university students, carrying out comprehensive medical screening of potential donors and following strictly monitored GMP in their laboratories (see Wahlberg 2010). There are many reasons why sperm banks recruit primarily from among university students, one of which is a suggestion that university students are in an age group that tends to have viable, if not lively sperm that has been less exposed, as one sperm bank administrator in Changsha explained:

Compared to people who have already begun working, the students' lifestyle is healthier. Because after work begins, you have to... sometimes for work, you smoke or drink and this is not good for sperm quality... and in China, most of the students when they begin university, they haven't had a sex life before, so this is also good for sperm quality. And also because they are young, they are not impacted by the environment. 
This paper has been accepted for publication in Science, Technology \& Society, and the final (edited, revised and typeset) version of this paper will be published in Science Technology \& Society: 23(2), April 2018 by Sage Publications Ltd, All rights reserved. () Sage Publications Ltd, 2018

His somewhat surprising views ${ }^{\mathrm{vi}}$ were echoed by a 20 year-old qualified donor in Shanghai: 'I think it's better to choose donors among university students, as our environment and lifestyle is better than people in the society'. And indeed, the Ministry of Health's Regulation on the Administration of Sperm Banks explicitly states that 'Semen shall not be collected if the candidate... has had longterm exposure to radiation and hazardous substances' (MoH 2003: §16).

If my argument holds, the sperm bank with its tanks of quality-controlled sperm can be thought of as a state-sanctioned sanctuary of reproductive vitality - quite literally so - at a time where this vitality is increasingly seen as under threat. Aggregated sperm quality deterioration acts as a kind of metaphor for the degradation that China's rapid transformation into an industrialised nation is held responsible for, a way to morally value the new forms of life and ways of living in China. The thing about 'quality' is not only that it is normative - the quality of something can be good or bad - but also that it is can improve or deteriorate along normative continuums or scales. Such continuums allow for an aggregated national sperm quality to be considered under threat, and hence in need of protection from all the pollutants, toxicants and stressors that might damage it. It is little wonder that sperm bank staff enjoyed their rostered shifts in the air-quality-controlled lab, just as I did while carrying out fieldwork. These hours were a welcome break from the traffic, smog and constant crowds of people that the sperm bank laboratory's hatch held at bay, the only interruptions coming when the on duty receptionist tapped on the window to indicate that the next batch of relatively unexposed sperm samples from university students had been delivered, waiting to be quality-controlled. 
This paper has been accepted for publication in Science, Technology \& Society, and the final (edited, revised and typeset) version of this paper will be published in Science Technology \& Society: 23(2), April 2018 by Sage Publications Ltd, All rights reserved. () Sage Publications Ltd, 2018

\section{Conclusions}

Zalasiewicz and colleagues have suggested that more than an actual geological time the Anthropocene is perhaps better understood as a 'vivid yet informal metaphor of global environmental change' (2008: 7; see also Wahlberg 2013). Similarly, I would suggest that fertility decline and aggregated sperm quality deterioration act as metaphors (among many others) for the degradation that China's rapid transformation into an industrialised nation is held responsible for. In an interview with founder of the Hunan sperm bank in Changsha, Lu Guangxiu, held in May 2011 I was struck by one of her final reflections: 'I think that of all the regulations from the Chinese Ministry of Public Health, those for human sperm banks and assisted reproductive technologies are the most successful, because all of these work, it really is going in a healthy way. I think that if we can do the same for quality security of our food it will work.' This comparison of regulating sperm banks to the task of food safety assurance resonates in China today because of a sense that vital quality is under threat, deteriorating in all kinds of ways. In such a milieu, the sperm bank emerges as a guarantor not only of individual sperm sample quality but also of the nation's very vitality in the face of apparently falling sperm counts and increasing male infertility, both of which have been blamed on environmental pollution by scientists, doctors, media and laypersons alike. The tanks of the sperm bank in Changsha contain much more than possible treatments for male-factor infertile couples, rather these steel tanks are a form of national reproductive insurance, protecting the frozen life within from exposure to the smog, industrial chemicals and mobile phone radiation that surround it.

\section{Acknowledgments}


This paper has been accepted for publication in Science, Technology \& Society, and the final (edited, revised and typeset) version of this paper will be published in Science Technology \& Society: 23(2), April 2018 by Sage Publications Ltd, All rights reserved. () Sage Publications Ltd, 2018

Research for this article was made possible by a generous Sapere Aude Young Researcher grant (no. 10-094341) from the Danish Council for Independent Research. My sincere thanks to Lu Guangxiu, Fan Liqing, Zhu Wenbing, He Jing, Nie Hongchuan, Hu Jing, Long Xingyu and all other staff members at the Hunan sperm bank for their kind assistance and support during fieldwork in Changsha. For translation and transcription assistance I would like to thank He Jing, Vicky Wang and Aelred Doyle. I am especially grateful to the many sperm donors and infertile couples who agreed to share their stories during my research.

\section{Author Bio}

Ayo Wahlberg is Professor MSO at the Department of Anthropology, University of Copenhagen. He is author of Good Quality - the Routinisation of Sperm Banking in China (forthcoming, University of California Press) and co-editor of Selective Reproduction in the 21 $1^{\text {st }}$ Century (2017, Palgrave Macmillan).

\section{References}

Bunkenborg, M. (2014). Subhealth: Questioning the quality of bodies in contemporary China. Medical Anthropology 33(2): 128-143.

Carlsen, E., Giwercman, A., Keiding, N. and Skakkebæk, N.E., (1992). Evidence for decreasing quality of semen during past 50 years. British Medical Journal 305(6854): 609-613.

Carson, R. (1962). Silent Spring. New York: Fawcett Crest. 
This paper has been accepted for publication in Science, Technology \& Society, and the final (edited, revised and typeset) version of this paper will be published in Science Technology \& Society: 23(2), April 2018 by Sage Publications Ltd, All rights reserved. () Sage Publications Ltd, 2018

Chen, Z., Wang, J.N., Ma, G.X. and Zhang, Y.S., (2013). China tackles the health effects of air pollution. The Lancet 382(9909): 1959-1960.

Colborn, T., vom Saal, F.S. and Soto, A.M., (1993). Developmental effects of endocrine-disrupting chemicals in wildlife and humans. Environmental Health Perspectives 101(5): .378.

Fortun, K. (2009). Advocacy after Bhopal: Environmentalism, disaster, new global orders. University of Chicago Press.

Guo, Y., Ma, Y., Chen, G. and Cheng, J., (2016). The Effects of Occupational Exposure of Carbon Disulfide on Sexual Hormones and Semen Quality of Male Workers From a Chemical Fiber Factory. Journal of Occupational and Environmental Medicine 58(8): e294-e300.

Hu, F.B., Liu, Y. and Willett, W.C., (2011). Preventing chronic diseases by promoting healthy diet and lifestyle: public policy implications for China. Obesity Reviews 12(7): 552-559.

Huang, C., Li, B., Xu, K., Liu, D., Hu, J., Yang, Y., Nie, H., Fan, L. and Zhu, W., (2017). Decline in semen quality among 30,636 young Chinese men from 2001 to 2015. Fertility and Sterility 107(1): 83-88.

Inhorn, M.C., (2013). Why me? Male infertility and responsibility in the Middle East. Men and Masculinities 16(1): 49-70.

Jiang, M., Chen, X., Yue, H., Xu, W., Lin, L., Wu, Y. and Liu, B., (2014). Semen quality evaluation in a cohort of 28213 adult males from Sichuan area of south $\square$ west China. Andrologia 46(8): 842847.

Lamoreaux, J., (2016). What if the Environment is a Person? Lineages of Epigenetic Science in a Toxic China. Cultural Anthropology 31(2): 188-214. 
This paper has been accepted for publication in Science, Technology \& Society, and the final (edited, revised and typeset) version of this paper will be published in Science Technology \& Society: 23(2), April 2018 by Sage Publications Ltd, All rights reserved. () Sage Publications Ltd, 2018

Landecker, H., (2011). Food as exposure: Nutritional epigenetics and the new metabolism. BioSocieties 6(2): 167-194.

Latour, B. (2014). Agency at the time of the Anthropocene. New Literary History 45: 1-18

Levine, H, Jørgensen, N, Martino-Andrade, A, Mendiola, J, Weksler-Derri, D, Mindlis, I, Pinotti, R, Swan, SH. (2017). Temporal trends in sperm count: a systematic review and meta-regression analysis. Human Reproduction Update. doi: 10.1093/humupd/dmx022

Liu, L. (2010). Made in China: cancer villages. Environment: Science and Policy for Sustainable Development 52(2): 8-21.

Lock, M. (1993). Encounters with Aging: Mythologies of Menopause in Japan and North America. Berkley: University of California Press

Lock, M. and Kaufert, P., (2001). Menopause, local biologies, and cultures of aging. American Journal of Human Biology 13(4): 494-504.

Lora-Wainwright, A., Zhang, Y., Wu, Y., \& Van Rooij, B. (2012). Learning to live with pollution: the making of environmental subjects in a Chinese industrialised village. The China Journal (68): $106-124$.

Lora-Wainwright, A. (2017). Resigned Activism: Living with Pollution in Rural China. Cambridge MA: The MIT Press

Marques-Pinto, A. and Carvalho, D., (2013). Human infertility: are endocrine disruptors to blame?. Endocrine Connections 2(3): R15-R29.

Martin, L. J. (2010). Anticipating infertility: Egg freezing, genetic preservation, and risk. Gender \& Society 24(4): 526-545. 
This paper has been accepted for publication in Science, Technology \& Society, and the final (edited, revised and typeset) version of this paper will be published in Science Technology \& Society: 23(2), April 2018 by Sage Publications Ltd, All rights reserved. () Sage Publications Ltd, 2018

Mertes, H., \& Pennings, G. (2011). Social egg freezing: for better, not for worse. Reproductive Biomedicine Online 23(7): 824-829.

MoH. (2003). The basic requirements and technical specifications of human sperm banks. Issued by the Ministry of Health, People's Republic of China, July 2003

Murphy, M., (2008). Chemical regimes of living. Environmental History 13(4): 695-703.

Murphy, M., (2011). Distributed Reproduction. In Paisley Currah and Monica Casper, eds. Corpus: Bodies of Knowledge. New York: Palgrave Macmillan. pp. 21-38

Murphy, M., (2013). Chemical Infrastructures of the St Clair River. In Soraya Boudia and Nathalie Jas, eds. Toxicants, Health and Regulation since 1945. London: Pickering and Chato. pp. 103-115.

Petryna, A. (2002). Life exposed: biological citizens after Chernobyl. Princeton University Press.

Rao, M., Meng, T.Q., Hu, S.H., Guan, H.T., Wei, Q.Y., Xia, W., Zhu, C.H. and Xiong, C.L., (2015). Evaluation of semen quality in 1808 university students, from Wuhan, Central China. Asian Journal of Andrology 17(1): 111.

Shapiro, N. (2015). Attuning to the chemosphere: Domestic formaldehyde, bodily reasoning, and the chemical sublime. Cultural Anthropology 30(3): 368-393.

Skakkebaek, N.E., Rajpert-De Meyts, E. and Main, K.M., (2001). Testicular dysgenesis syndrome: an increasingly common developmental disorder with environmental aspects: Opinion. Human Reproduction 16(5): 972-978.

Tjørnhøj-Thomsen, T (2009). "It's a bit unmanly in a way": Men and Infertility in Denmark. in MC Inhorn, T Tjørnhøj-Thomsen, H Goldberg \& M la Cour Mosegaard (eds), Reconceiving the Second Sex: Men, Masculinity and Reproduction. Oxford: Berghahn Books. pp. 226-252. 
This paper has been accepted for publication in Science, Technology \& Society, and the final (edited, revised and typeset) version of this paper will be published in Science Technology \& Society: 23(2), April 2018 by Sage Publications Ltd, All rights reserved. () Sage Publications Ltd, 2018

Tsing, A., Bubandt, N.O., Gan, E. and Swanson, H.A., (2017). Arts of Living on a Damaged Planet: Ghosts and Monsters of the Anthropocene. University of Minnesota Press

UNEP \& WHO. (2013). State of the science of endocrine disrupting chemicals - 2012: An assessment of the state of the science of endocrine disruptors prepared by a group of experts for the United Nations Environment Programme (UNEP) and WHO. Geneva: WHO

Wahlberg. (2010). Assessing Vitality: Infertility and Good Life in Urban China. In Yorke, J. (ed) The Right to Life and the Value of Life: Orientations in Law, Politics and Ethics, Ashgate Publishing, Ltd. pp. 371-98.

Wahlberg. (2013). Human Activity between Nature and Society: The Negotiation of Infertility in China. In K Hastrup (ed.), Anthropology and Nature. London: Routledge Falmer. Pp. 184-195. Wahlberg, A. (2016). The birth and routinisation of IVF in China. Reproductive Biomedicine \& Society Online, 2: 97-107.

Wang, L., Zhang, L., Song, X.H., Zhang, H.B., Xu, C.Y. and Chen, Z.J., (2016). Decline of semen quality among Chinese sperm bank donors within 7 years (2008-2014). Asian journal of andrology.

Whyte, M. (2013). Episodic fieldwork, updating, and sociability. Social Analysis 57(1): 110-121.

Wong, K. K. (2003). The environmental awareness of university students in Beijing, China. Journal of Contemporary China 12(36): 519-536.

Wu, L., Jin, L., Shi, T., Zhang, B., Zhou, Y., Zhou, T., Bao, W., Xiang, H., Zuo, Y., Li, G. and Wang, C., (2017). Association between ambient particulate matter exposure and semen quality in Wuhan, China. Environment International 98: 219-228.

Zalasiewicz, J., M. Williams et al. (2008). Are We Now Living in the Anthropocene? GSA Today 18(2): 4-8. 
This paper has been accepted for publication in Science, Technology \& Society, and the final (edited, revised and typeset) version of this paper will be published in Science Technology \& Society: 23(2), April 2018 by Sage Publications Ltd, All rights reserved. () Sage Publications Ltd, 2018

Zalasiewicz, J., M. Williams, W. Steffen, \& P. Crutzne (2010). The New World of the Anthropocene. Environmental Science and Technology 44: 2228-31.

Zhang SC, Wang HY, Wang JD. 1999. Analysis of change in sperm quality of Chinese fertile men during 1981-1996 [in Chinese]. Reproduction \& Contraception 10: 33-39.

\section{Media reports}

CCTV.2011. 70\% of Chinese suffer from "sub-health" problems. 9 August 2011. Available at: http://english.cntv.cn/program/china24/20110809/103624.shtml, Accessed on 29 October 2016.

China Daily. 2009. Male infertility rate on the rise. 2 April 2009. available at: http://www.chinadaily.com.cn/cndy/2009-04/02/content_7640758.htm, accessed on 21 May 2011

China Daily 2011. More than a million men sterile in China. 7 November 2011. Available at: chinadailycom.91song.cc/china/2011-11/07/content_14051476.htm, accessed on 12 May 2012

Dàhé Jiànkāng Bào 2008 "National Emergency in Sperm banks in China - Only 37 qualified sperm out of 328 sperm donors in Henan", 1 December 2008, available at:http://tech.icxo.com/htmlnews/2008/12/01/1322076_0.htm, accessed on 11 May 2012

Politiken. 2007. Forsker advarer: Som art er vi i fare. 1 June 2007. Available at: http://politiken.dk/tjek/sundhedogmotion/familieliv/ECE316044/forsker-advarer-som-arter-vi-i-fare/, accessed on 24 September 2010. 
This paper has been accepted for publication in Science, Technology \& Society, and the final (edited, revised and typeset) version of this paper will be published in Science Technology \& Society: 23(2), April 2018 by Sage Publications Ltd, All rights reserved. () Sage Publications Ltd, 2018

Qingdao News 2005. "The data shows that sperm crisis era has come - Sperm quality declines of 1\% per year" 3 June 2005, available at: http://www.qingdaonews.com/content/200506/03/content_4822001.htm, accessed on 12 May 2011

Reuters 2007. Pollution, stress blamed for poor China sperm count. 9 April 2007. Available at: http://www.reuters.com/article/us-china-health-fertility-idUSPEK29006120070409, accessed on 21 May 2011

Shanghai News Channel 2008. "Shanghai Sperm Bank urgent situation; sperm crisis era begins", available at: http://www.315rencai.cn/play.php?id=XMTM3MTQzNDMy, accessed on 10 July 2012

Sina News 2011. The "the sperm crisis" in the world. 6 June 2011, available at: http://news.sina.com.cn/c/2011-01-06/093321769340.shtml, accessed on 5 March 2012

Sina News 2008. "Sperm quality is declining and male infertility is rising" 25 September 2008, available at: http://baby.sina.com.cn/health/08/2509/1008121546.shtml, accessed on 14 March 2012

Sohu News. 2011. Sperm is affected by environment: Various kinds of pollutions make sperm quality decline. 25 February 2011. available at: http://green.sohu.com/20110225/n279524333.shtml, accessed on 9 October 2012

South China Morning Post. Smog crisis in China leads to increased research into effect of pollution on fertility. 11 December 2013, available at: http://www.scmp.com/news/china/article/1378103/china-boosts-research-effect-pollutionfertility-amid-smog-crisis, accessed on 5 December 2015 
This paper has been accepted for publication in Science, Technology \& Society, and the final (edited, revised and typeset) version of this paper will be published in Science Technology \& Society: 23(2), April 2018 by Sage Publications Ltd, All rights reserved. () Sage Publications Ltd, 2018

Xtata 2010. "The prevalence of male infertility in Guangzhou is increasing dramatically", available at http://gz.xtata.com/g/20100605/58536796.shtml, accessed on 10 May 2011

Washington Post 2010. Study: BPA has effect on sperm, 28 October 2010, available at: http://www.washingtonpost.com/wpdyn/content/article/2010/10/27/AR2010102707803.html, accessed on 20 May 2011 Zhang, C. 2016. Chinese Women Head Overseas to Freeze Their Eggs. New York Times. 30 August 2016, https://www.nytimes.com/2016/08/31/world/asia/china-us-womenfertility.html, accessed on 1 July 2017

Zhao, Zhenyu (2008) 'Experts say: serious sperm problem, in 60 years, 62\% decline', in, Global Times - Life Times [环球时报-生命时报]

(http://health.sohu.com/20080729/n258448484.shtml: accessed on 30 July 2008.

\section{Endnotes}

\footnotetext{
${ }^{\mathrm{i}}$ My informants at the sperm bank in Changsha have rightly pointed out that even if environmental pollution is implicated in rising rates of male infertility and falling sperm quality, there are other factors that play a much more important role when accounting for rising rates of overall infertility such as reproductive deferral, lifestyle changes, changing sex life patterns and the spread of sexually transmitted diseases. My argument in this article is not that pollution is the prime culprit for apparently rising infertility rather I show how it has gained traction as a kind of social diagnostic of some of the many dramatic transformations China is currently undergoing.

${ }^{\text {ii }}$ In July 2017, Levine et al. published an updated meta-review which likewise concluded that sperm counts 'declined 52.4\% between 1973 and 2011 among unselected men from Western countries, with no evidence of a "leveling off" in recent years" (Levine et al. 2017: 14).

iii Not least because inconsistent methodologies for sperm quality assessment made it difficult to compare with historical data and also because some were convinced that lifestyle changes and increased sexual activity among young men, rather than any kind of biological deterioration per se, were the most likely explanation for any measured drop in aggregate quality over time.

${ }^{i v}$ This warning was reiterated recently by Hagai Levine following publication of his updated meta-review of global sperm counts (Levine et al. 2017): 'If we will not change the ways that we are living and the environment and the chemicals that we are exposed to, I am very worried about what will happen in the future. Eventually we may have a problem, and with reproduction in general, and it may be the extinction of the human species.' (cited in BBC News 2017)
} 
This paper has been accepted for publication in Science, Technology \& Society, and the final (edited, revised and typeset) version of this paper will be published in Science Technology \& Society: 23(2), April 2018 by Sage Publications Ltd, All rights reserved. () Sage Publications Ltd, 2018

\footnotetext{
${ }^{v}$ As I have already noted, it is important to keep in mind that even if it is a fact that aggregate sperm quality levels are falling around the world, reproductive deferral remains the most important factor in fertility transitions from high- to low-fertility. What I am analyzing in this article is how the routinisation of sperm banking became possible in China.

${ }^{{ }^{v i}}$ I will leave it to others to empirically challenge this sperm bank director's take on the relatively less exposed biologies and healthier lifestyles of university students today in China, what I am analyzing here is how ideas about exposure shape recruitment practices.
} 